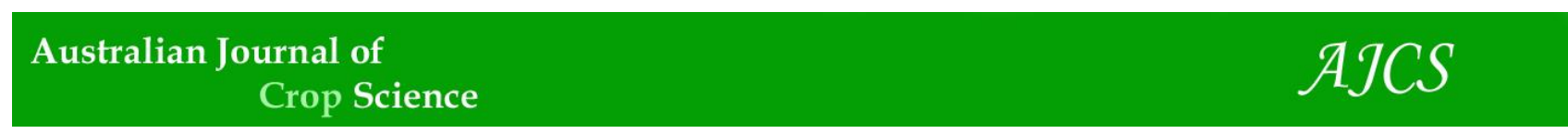

AJCS 12(01):51-55 (2018)

ISSN:1835-2707

doi: 10.21475/ajcs.18.12.01.pne643

\title{
Effect of different plant beds and fertilizers on Stevia (Stevia rebaudiana Bertoni) production
}

\author{
Robabeh Asghari \\ Plant Production Department, Imam Khomeini Higher Education Centre, Agricultural Research, Education and \\ Extension Organization (AREEO), Karaj, Iran
}

*Corresponding author: fariba2022@yahoo.com

\begin{abstract}
Stevia rebaudiana Bertoni is well-known for its high content of steviol glycoside, a diterpene compound (about 4-20\%) in dryleaf matter that is responsible for providing the non-caloric value sweet taste. Steviol glycosides are natural sugar substitutes for diabetics and other people on carbohydrate-controlled diets. Studies revealed that the glycosides yield, especially stevioside, greatly depends on the total biomass yield, which in turn depends on agricultural practices for cultivation of stevia. In this study, the effect of five various combinations of soil, cocopeat, perlite, and vermicompost plant beds mixed with four different fertilizers of tea compost, vermiwash, Hoagland and water, on four different physiological (leaf area, stem length, fresh weight and dry weight) and six different biochemical (chlorophyll content, carotenoid, protein, glucose, phenols and rebaudiosides) characteristics of plant were evaluated. To gain the highest content of biochemical compounds, especially all types of rebaudiosides, a combination of vermicompost, perlite and cocopeat with vermiwash or any other fertilizers can be useful.
\end{abstract}

Keywords: Fertilizer; Growth bed; Natural sweeter; Organic fertilizer; Rebaudioside.

\section{Introduction}

Stevia rebaudiana Bertoni branched bushy shrub of the Asteraceae family, is native to the north-east region of Paraguay, also grows in the neighboring parts of Brazil and Argentina (Soejarto, 2002). Nowadays, stevia is known for its high content of sweet diterpene (about 4-20\%) in the dryleaf matter (Ghanta et al. 2007) and the stevia glycosides are responsible compounds for the sweet taste. From 230 species of Stevia genus, only the species rebaudiana and phlebophylla produce steviol glycosides (Brandle and Telmer, 2007). The analysis by liquid chromatography coupled with UV, MS and ELS detection showed that the Steviol is as common aglycone backbone of the sweet stevia glycosides (Cacciola et al. 2011). Stevioside, reported as most abundant stevia glycoside $(4-13 \% \mathrm{w} / \mathrm{w})$ found mainly in plant leaves followed by stems, seeds and roots, which is about 300 times sweeter than sucrose and can be particularly useful to those suffering from obesity, diabetes mellitus, heart disease and dental caries (Ghanta et al., 2007). Stevia stays well in a wide range of soils with a consistent supply of moisture and adequate drainage (Shock, 1982). The longer days are favored to leaf yield and stevioside contents. Stevia is sensitive to cold and does not usually tolerate temperatures below $9^{\circ} \mathrm{C}$, while, the rapid growth occurs at 20-24 ${ }^{\circ} \mathrm{C}$ (Singh and Rao, 2005).

Studies reveal that the glycosides yield, especially stevioside, greatly depends on the total biomass yield, which in turn depends on agricultural practices for cultivation of stevia plants (Geuns, 2003). To achieve high production of glycosides, an adaptation of modern agro-techniques (Das et al., 2008), water management (Fronza and Folengatti, 2003) and fertilizer applications (Mamta et al., 2010) are needed.
In addition, in vitro culture techniques and application of bioreactors have also been tested (Madan et al. 2010). Among those, reliable nutrient supply is crucial for plant yield production. The optimum requirement of macro and micro nutrients essential for normal growth are gained from different types of soil composition and fertilizers. However, the main limiting factors are high costs and low on-farm feasibility. For instance, chemical fertilizers constitute a few mineral nutrients and create an imbalance in the whole mineral pattern of the plant body by hindering the uptake of other useful nutrients (Das et al., 2008). Also, there is growing concern over the adverse effects of using chemical fertilizers, pesticides, and herbicides on soil productivity and environment quality. Therefore, organic structure of plant growth fertilizers and soil mixtures, which results in high plant yield, are in demand.

Recently, the contrasting effect of organic and chemical fertilizers, microorganism's interaction effects on plant growth, mixed fertilizers and their effect on physiological and biochemical characteristics of plant have been studied (Liu et al., 2011; Mandal et al., 2013; Patil, 2010; Vafadar et al., 2014; Yang et al., 2013). While these studies have great value to achieve high yield stevia production, the study of soil structure and its mixed fertilizers followed by knowing of which mixture have the maximum effect, still lacking. The objective of our study was to evaluate the effect of different plant beds mixed with different fertilizers to find out the suitable nutrient source for stevia production. 


\section{Results}

Here four different physiological (leaf area, stem length, fresh weight and dry weight) and six different biochemical (chlorophyll content, carotenoid, protein, glucose, phenols, and rebaudiosides) characteristics of the plant were analyzed. The analysis of variance showed significant following differences among all characters $(P<0.01)$ (Table 4):

A. Leaf area: The highest leaf area was found in plant bed G12 $\left(16.6 \mathrm{~cm}^{2}\right)$ followed by G15, G11 and G9 with 16.2, 16 and $14.9 \mathrm{~cm}^{2}$ respectively, while least leaf area was shown in G1 $\left(7.3 \mathrm{~cm}^{2}\right)$ (Table 5 and figure 1 ).

B. Stem length: Stem length was found to be most effective by bed G11, which reached the peak of $36.0 \mathrm{~cm}$ followed by G14 and G3 $(33.7$ and $31.3 \mathrm{~cm})$. The shortest length was found in $\mathrm{G} 1$ with $13.9 \mathrm{~cm}$ (Table 5).

C. Fresh weight: The highest fresh weight was in bed G15 $(0.33 \mathrm{~g})$ which was not significantly different from G11, and G12 $(0.29 \mathrm{~g})$ but different with others. Also, G6 (0.14 g) had least fresh weight followed by G1 and G2 (0.15 and $0.16 \mathrm{~g})$ with non-significant different from each other (Table 5).

D. Dry weight: On dry weight examination, the highest weight was found in $\mathrm{G} 11(0.072 \mathrm{~g})$ followed non-significantly by $\mathrm{G} 7$ and $\mathrm{G} 12$ (0.071 and $0.068 \mathrm{~g}$ ), and the lowest dry weight was in $\mathrm{G} 6(0.035 \mathrm{~g})$ followed non-significantly by $\mathrm{G} 2$, G1, and G13 (Table 5 and figure 2).

The analysis of variance in biochemical studies shows significant following differences in those characterizations and the treatments applied $(P<0.01)$ (Table 4$)$ :

A. Chlorophyll a: The highest amount of chlorophyll awas found in G8 (18.8 mg/gFW) followed by G7 and G13 (18.4 and $18.3 \mathrm{mg} / \mathrm{gFW})$, while the lowest amount calculated in G6 (10.5 mg/gFW) followed by G15 (10.7 mg/gFW).

B. Chlorophyll b and carotenoid: It was almost same in chlorophyll a and carotenoid, which the highest amount of those found in G8, 8.46 and $2.83 \mathrm{mg} / \mathrm{gFW}$ respectively. The lowest amount also showed in G6 and G15 in those factors (Table 5).

C. Protein, glucose, and phenols: The protein content found most in G3 (3.26\%) and least in G7 (0.92\%) (Table 5). The highest amount of glucose and phenols calculated in G6 by 758.2 and $153.2 \mathrm{mg} / \mathrm{gDW}$ respectively, while the G16 showed the lowest amount of those factors (Table 5).

D. Rebaudiosides: The sweet responsible agent, rebaudiosides, found thehighest amount in G4 (184.3 $\mathrm{mg} / \mathrm{gDW}$ ) and least in $\mathrm{G} 10, \mathrm{G} 13$, and $\mathrm{G} 11$ respectively, which were not significantly different (Table 5 ). There are several reports of higher carbohydrate concentrations on different soil structures (Schaarschmidt et al., 2006; Wu et al. 2011).

\section{Discussion}

The results show that, by using planting bed combination like G11, the highest physiological characterization can be achieved without any additional fertilizer. This can prove the important effect of beds compared to fertilizers in the case of stevia plant cultivation, as the lowest physiological characterization found in the control treatment. The variation among physiological characters was observed by different studies facing biological soil composition treatments (Mandal et al., 2013). These can be due to changes occurred in the soil structure and could be effective on root surface area for absorption of nutrients and water (Jefferies et al., 2003). Pal et al., (2015) were analyzed the effect of different soil nutrition due to different crop-ecology. They found a significant effect of environmental factors and agronomic management on dry leaf yield. The biomass is also dependent on its ability to improve photosynthesis.

Stable nutrient status has also been reported to contribute to a net increase in photosynthesis in plants (Giri et al. 2003). By studying the results, we can realize, the presence of vermicompost in planting beds is most important in comparing with the other factors in the case of chlorophyll and carotenoid content of the plant. Also, the fertilizer composition does not have a significant effect on these factors, while, the suggested nutrient agent can be vermiwash and teacompost. In contrast, the nutrient composition (Hoagland) has shown essential to the accumulation of proteins, as its effect alone was significant.

Study of glucose, phenols and rebaudiosides results shows the important effect of cocopeat and its amount on stevia planting beds, as the highest amount of cocopeat combined with pearlite results an accumulation of those important chemicals. To achieve the highest amount of biochemical compound especially rebaudiosides, a combination of vermicompost, perlite and cocopeat combined with vermiwash or any other fertilizer can be useful. Here, adding vermicompost to the G4 combination may achieve the results. Pal et al., (2015) also suggested, the proper nutritional management and environmental factors increase secondary metabolites significantly.

\section{Materials and methods}

The fertilizers and soils used in this study were made and analyzed for nutrient componentsin plant production department (Table 2\&3). The Plant samples of Stevia rebaudiana(Bertoni) were obtained from biotechnology department of jihad-e-daneshgahi Institute, Karaj, Iran,and grown in $30 \mathrm{~cm}$ wide diameter (Volume $3 \mathrm{~L}$ ) earthen pot on the terrace at the greenhouse to reach normal day and night light condition with $25 / 17^{\circ} \mathrm{C}$ temperature.

\section{Morphological measurement}

For growth observation, total fresh leaves area and stem length were quantified. After recording the fresh weight of above and below ground parts of plants, green-killing treatment was done at $105^{\circ} \mathrm{C}$ and the samples were oven dried at $70 \pm 2^{\circ} \mathrm{C}$ until a constant weight was attained to calculate the percentage of dry matter accumulation.

\section{Chlorophyll and carotenoid content}

Leaves were collected from the experimental unit to chlorophyll content estimation. The fractions of pigments (chlorophyll a, chlorophyll b, and total chlorophyll) were estimated using the spectrophotometric method recommended by Arnon (1949). $200 \mathrm{mg}$ fresh leaf sample was separated from each sample. Chlorophyll was extracted in a solution of $80 \%$ acetone $(\mathrm{v} / \mathrm{v})$. Subsequently, the 
Table 1. Sowing bed compositions (G1 - G16) and different organic fertilizers.

\begin{tabular}{|c|c|c|c|c|c|}
\hline Name & Sowing bed & Fertilizer & Name & Sowing bed & fertilizer \\
\hline G1 & $100 \%$ Soil & Tea compost & G9 & 40\%vearmicompost+60\%pearlite & Water \\
\hline G2 & 100\%Soil & Vermiwash & G10 & $30 \%$ vermicompost $+60 \%$ perlite $+10 \%$ Cocopeat & Tea compost \\
\hline G3 & $100 \%$ Soil & Hoagland & G11 & $30 \%$ vermicompost $+60 \%$ perlite $+10 \%$ Cocopeat & Water \\
\hline G4 & $40 \%$ Cocopeat+60\%perlite & Vearmiwash & G12 & $30 \%$ vermicompost $+60 \%$ perlite $+10 \%$ Cocopeat & Vermiwash \\
\hline G5 & $40 \%$ Cocopeat+60\%perlite & Hoagland & G13 & $60 \%$ Soil+40\%vermicompost & Tea compost \\
\hline G6 & $40 \%$ cocopeat $+60 \%$ perlite & Tea compost & G14 & $60 \%$ Soil+40\%vermicompost & Vermiwash \\
\hline G7 & $40 \%$ vermicompost+60\%perlite & Tea compost & G15 & $60 \%$ Soil+40vermicompost & Hoagland \\
\hline G8 & $40 \%$ vearmicompost $+60 \%$ perlite & Vearmiwash & G16 & $100 \%$ Soil & Water \\
\hline
\end{tabular}

Note: Water without any amount of fertilizers is used as a control

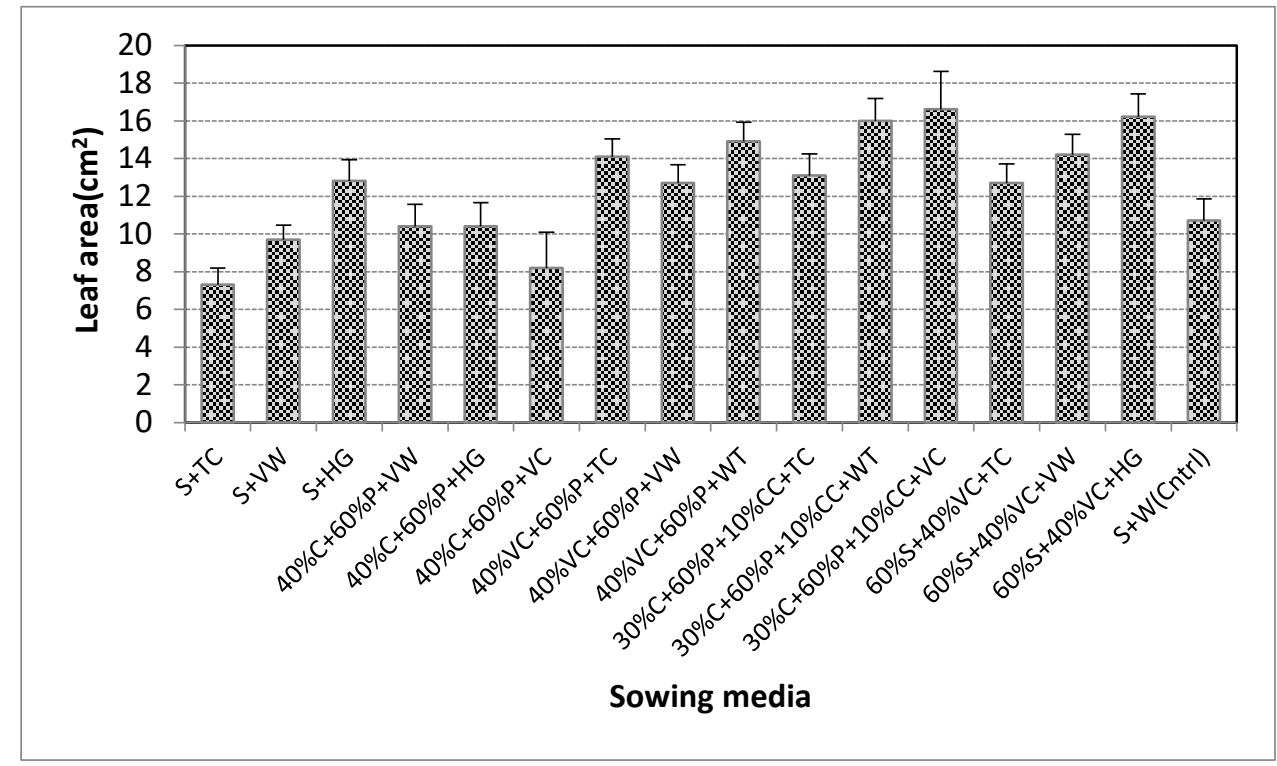

Fig 1. The leaf area in different sowing media.

Table 2. Chemical analyses of organic fertilizers.

\begin{tabular}{|c|c|c|c|c|c|c|c|c|c|c|c|}
\hline $\begin{array}{l}\text { Fertilizer } \\
\text { component }\end{array}$ & $\mathrm{Mg}(\%)$ & $\begin{array}{l}\mathrm{Ca} \\
(\%)\end{array}$ & N\% & $\mathrm{P}(\%)$ & Fe (ppm) & $\begin{array}{c}\mathrm{Zn} \\
(\mathrm{ppm})\end{array}$ & $\begin{array}{c}\mathrm{Mn} \\
(\mathrm{ppm})\end{array}$ & $\begin{array}{c}\mathrm{K} \\
(\%)\end{array}$ & $\begin{array}{l}\mathrm{Na} \\
(\%)\end{array}$ & $\begin{array}{c}\text { EC } \\
\left(\mu \mathrm{s} / \mathrm{cm}^{2}\right)\end{array}$ & $\mathrm{pH}$ \\
\hline Vermiwash & 0.104 & 0.256 & 0.046 & 0.029 & 6.676 & 163.5 & 56.44 & 0.504 & 0.047 & 470 & 7.58 \\
\hline Teacompost & 0.413 & 0.453 & 0.046 & 0.331 & 82.988 & 320.46 & 56.44 & 6.334 & 0.071 & 2300 & 6.77 \\
\hline Vermicompost & 0.334 & 0.44 & 0.046 & 0.298 & 89.045 & 343.35 & 67.38 & 6.125 & 0.072 & 2200 & 6.95 \\
\hline
\end{tabular}

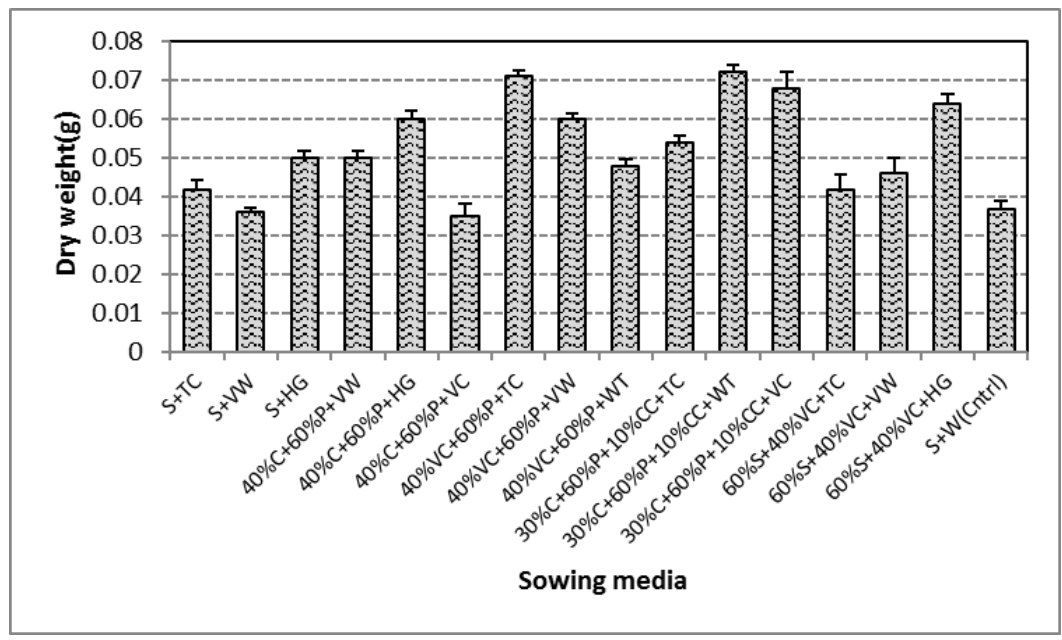

Fig 2. The plant dry weight in different sowing media.

Table 3. Chemical analyses of soil.

\begin{tabular}{ccccccc}
\hline Soil & $\mathrm{P}(\mathrm{ppm})$ & $\mathrm{N}(\%)$ & $\mathrm{K}(\mathrm{ppm})$ & $\mathrm{OC}(\%)$ & $\mathrm{pH}$ & $\mathrm{EC}\left(\mathrm{ms} / \mathrm{cm}^{2}\right)$ \\
\cline { 2 - 6 } & 260.7685 & 2.776667 & 210.4931 & 24.91043 & 8.45 & 5.9 \\
\hline
\end{tabular}


Table 4. Analysis of variance for different biological and biochemical factors.

\begin{tabular}{lccc}
\hline Changes sources & Treatment & Error & $\mathrm{cV}$ \\
\hline Leaf area $\left(\mathrm{cm}^{2}\right)$ & $22.24^{*}$ & 5.78 & 7.1 \\
Stem length $(\mathrm{cm})$ & $85.58^{*}$ & 17.530 & 7.4 \\
Fresh weight $(\mathrm{g})$ & $0.00861^{*}$ & 0.001 & 19.3 \\
Dry weight $(\mathrm{g})$ & $0.000449^{*}$ & 0.000083 & 14.1 \\
df & 15 & 31 & \\
Chlorophyll a (mg/gFW) & $21.332^{*}$ & 12.93 & 7.4 \\
Chlorophyll b (mg/gFW) & $6.693^{*}$ & 0.009 & 2.1 \\
Carotenoid (mg/gFW) & $0.996^{*}$ & 0.002 & 3.1 \\
Protein \% & $1.286^{*}$ & 0.002 & 2.5 \\
df & 15 & 31 & \\
Glucose (mg/gDW) & $9031.1^{*}$ & 45.4 & 15.3 \\
Phenols (mg/gDW) & $3459.3^{*}$ & 5.6 & 2.6 \\
Rebaudiosides (mg/gDW) & $7871.2^{*}$ & 4.4 & 3.5 \\
df & 7 & 16 & \\
\hline
\end{tabular}

*Significant at $1 \%$; df: Degrees of freedom.

Table 5. Comparative analysis of different physiological and biochemical factors. The values in the column with similar alphabets are non-significant with each other ( $\mathrm{P} \leq 0.05)$.

\begin{tabular}{|c|c|c|c|c|c|c|c|c|c|c|c|}
\hline Treatment & $\begin{array}{l}\text { Leaf area } \\
\left(\mathrm{cm}^{2}\right)\end{array}$ & $\begin{array}{l}\text { Stem } \\
\text { length } \\
(\mathrm{cm})\end{array}$ & $\begin{array}{l}\text { Fresh } \\
\text { weight } \\
\text { (g) }\end{array}$ & $\begin{array}{l}\text { Dry } \\
\text { weight } \\
\text { (g) }\end{array}$ & $\begin{array}{l}\text { Chlorophylla } \\
\text { (mg/gFW) }\end{array}$ & $\begin{array}{l}\text { Chlorophyllb } \\
\text { (mg/gFW) }\end{array}$ & $\begin{array}{l}\text { Carotenoid } \\
\text { (mg/gFW) }\end{array}$ & $\begin{array}{l}\text { Protein } \\
\%\end{array}$ & $\begin{array}{l}\text { Glucose } \\
\text { (mg/gDW) }\end{array}$ & $\begin{array}{l}\text { Phenols } \\
\text { (mg/gDW) }\end{array}$ & $\begin{array}{l}\text { Rebaudiosides } \\
\text { (mg/gDW) }\end{array}$ \\
\hline G1 & $7.3^{d}$ & $13.9^{\mathrm{g}}$ & $0.15^{\mathrm{e}}$ & $0.042^{\text {def }}$ & $15.7^{\text {de }}$ & $4.50^{\mathrm{fg}}$ & $1.44^{h}$ & $1.90^{f}$ & $398.2^{h}$ & $80.7^{i}$ & $57.8^{h}$ \\
\hline $\mathrm{G} 2$ & $9.7^{c d}$ & $23.5^{\text {def }}$ & $0.16^{\mathrm{e}}$ & $0.036^{\text {ef }}$ & $16.7^{\text {cd }}$ & $5.18^{\mathrm{e}}$ & $1.63^{f}$ & $2.26^{d}$ & $429.7^{f}$ & $86.2^{\mathrm{gh}}$ & $77.8^{\mathrm{g}}$ \\
\hline G3 & $12.8^{\mathrm{abc}}$ & $31.3^{\mathrm{abc}}$ & $0.20^{\mathrm{de}}$ & $0.050^{\text {cd }}$ & $17.4^{b c}$ & $5.79^{d}$ & $1.74^{\mathrm{e}}$ & $3.26^{a}$ & $454.5^{\mathrm{e}}$ & $92.0^{\text {ef }}$ & $58.1^{h}$ \\
\hline $\mathrm{G} 4$ & $10.4^{\mathrm{bcd}}$ & $20.2^{\text {ef }}$ & $0.19^{\mathrm{de}}$ & $0.050^{\text {cd }}$ & $13.3^{f}$ & $3.81^{i}$ & $1.06^{\mathrm{k}}$ & $1.42^{h}$ & $625.6^{c}$ & $126.3^{c}$ & $184.3^{\mathrm{a}}$ \\
\hline G5 & $10.4^{\mathrm{bcd}}$ & $25.7^{\text {cde }}$ & $0.21^{\mathrm{de}}$ & $0.060^{\mathrm{abc}}$ & $17.2^{\mathrm{bc}}$ & $5.22^{\mathrm{e}}$ & $1.67^{\text {ef }}$ & $1.23^{i}$ & $728.9^{b}$ & $147.2^{b}$ & $180.3^{b}$ \\
\hline G6 & $8.2^{d}$ & $25.3^{\text {cde }}$ & $0.14^{\mathrm{e}}$ & $0.035^{f}$ & $10.5^{g}$ & $2.89^{j}$ & $0.84^{\prime}$ & $1.00^{\mathrm{j}}$ & $758.2^{\mathrm{a}}$ & $153.2^{a}$ & $158.9^{c}$ \\
\hline G7 & $14.1^{\mathrm{ab}}$ & $21.4^{\mathrm{ef}}$ & $0.28^{\mathrm{abc}}$ & $0.071^{\mathrm{a}}$ & $18.4^{\mathrm{ab}}$ & $6.80^{\mathrm{b}}$ & $2.70^{b}$ & $0.92^{k}$ & $248.1^{k}$ & $50.1^{\prime}$ & $117.3^{d}$ \\
\hline G8 & $12.7^{\mathrm{abc}}$ & $18.3^{\mathrm{fg}}$ & $0.23^{\mathrm{bcd}}$ & $0.060^{\mathrm{abc}}$ & $18.8^{\mathrm{a}}$ & $8.46^{a}$ & $2.83^{\mathrm{a}}$ & $1.92^{\text {ef }}$ & $263.3^{j}$ & $76.0^{\mathrm{j}}$ & $106.2^{\mathrm{e}}$ \\
\hline G9 & $14.9^{\mathrm{a}}$ & $28.4^{\mathrm{bcd}}$ & $0.18^{\text {de }}$ & $0.048^{\text {cde }}$ & $14.2^{\text {ef }}$ & $4.65^{f}$ & $1.54^{\mathrm{g}}$ & $2.65^{b}$ & $435.0^{f}$ & $88.1^{\mathrm{g}}$ & $91.3^{f}$ \\
\hline G10 & $13.1^{\mathrm{abc}}$ & $26.2^{\text {cde }}$ & $0.24^{\mathrm{bcd}}$ & $0.054^{\text {bcd }}$ & $14.3^{\text {ef }}$ & $4.16^{\mathrm{h}}$ & $1.33^{i}$ & $1.95^{\text {ef }}$ & $439.1^{f}$ & $89.7^{\mathrm{fg}}$ & $35.2^{\mathrm{k}}$ \\
\hline G11 & $16.0^{\mathrm{a}}$ & $36.0^{\mathrm{a}}$ & $0.29^{a}$ & $0.072^{\mathrm{a}}$ & $12.9^{f}$ & $3.70^{i}$ & $1.17^{\mathrm{j}}$ & $1.57^{\mathrm{g}}$ & $588.1^{d}$ & $119.0^{d}$ & $38.6^{\mathrm{k}}$ \\
\hline G12 & $16.6^{a}$ & $26.5^{\text {cde }}$ & $0.29^{a}$ & $0.068^{\mathrm{a}}$ & $13.0^{f}$ & $3.78^{i}$ & $1.21^{j}$ & $2.57^{c}$ & $411.1^{\mathrm{g}}$ & $83.1^{\mathrm{hi}}$ & $52.1^{i}$ \\
\hline G13 & $12.7^{\mathrm{abc}}$ & $21.5^{\mathrm{ef}}$ & $0.20^{\mathrm{de}}$ & $0.042^{\text {def }}$ & $18.3^{\mathrm{ab}}$ & $6.45^{c}$ & $2.17^{c}$ & $1.53^{g}$ & $280.1^{i}$ & $56.3^{k}$ & $38.0^{k}$ \\
\hline G14 & $14.2^{\mathrm{ab}}$ & $33.7^{\mathrm{ab}}$ & $0.22^{\mathrm{cd}}$ & $0.046^{\text {def }}$ & $15.0^{\mathrm{e}}$ & $4.39^{\mathrm{g}}$ & $1.38^{\mathrm{hi}}$ & $2.22^{d}$ & $395.3^{\mathrm{h}}$ & $80.1^{i}$ & $43.6^{j}$ \\
\hline G15 & $16.2^{\mathrm{a}}$ & $25.5^{\text {cde }}$ & $0.33^{\mathrm{a}}$ & $0.064^{\mathrm{ab}}$ & $10.7^{\mathrm{g}}$ & $2.82^{j}$ & $0.89^{\prime}$ & $1.99^{\mathrm{e}}$ & $464.3^{\mathrm{e}}$ & $94.1^{\mathrm{e}}$ & $48.5^{i}$ \\
\hline G16 & $10.7^{\mathrm{bcd}}$ & $25.5^{\text {cde }}$ & $0.19^{\text {de }}$ & $0.037^{\text {ef }}$ & $17.6^{\mathrm{bc}}$ & $5.66^{d}$ & $1.83^{d}$ & $1.07^{j}$ & $105.3^{k}$ & $21.5^{\mathrm{m}}$ & $50.4^{i}$ \\
\hline
\end{tabular}

absorbance of samples at 645 and $663 \mathrm{~nm}$ was recorded by spectrophotometer. A pinch of $\mathrm{CaCO} 3$ was added to avoid destruction of chlorophyll and other pigments. Chlorophyll contents concentrations were calculated as $\mathrm{mg} \mathrm{g}^{-1} \mathrm{FW}$.

\section{Total soluble sugars}

The amount of total soluble sugars was estimated using anthrone reagents as given by Thimmaiah (2004). $100 \mathrm{mg}$ sample from the tissue culture derived from plants 6 months after transplanting to the pots, was taken in a boiling tube and hydrolyzed with $5 \mathrm{ml} 2.5 \mathrm{~N} \mathrm{HCl}$ in a water bath for $3 \mathrm{~h}$. It was then neutralized with solid sodium carbonate until effervescence ceased. The volume was made to $100 \mathrm{ml}$ followed by centrifuge at $5000 \mathrm{rpm}$ for $10 \mathrm{~min}$. The supernatant was collected and $1 \mathrm{ml}$ sample was taken for analysis. $4 \mathrm{ml}$ anthrone reagent was added to aliquot and heated in a water bath $\left(70^{\circ} \mathrm{C}\right)$ for $1 \mathrm{~min}$. The sample rapidly cooled and the change of green to dark green color was read at $630 \mathrm{~nm}$ against blank.

\section{Total Phenols}

Total phenolic compounds were determined by the FolinCiocalteau method. The extract samples $(20 \mu \mathrm{l})$ were mixed with FolinCiocalteau reagent $(100 \mu \mathrm{l})$ for 5 minutes and then aqueous $\mathrm{Na2Co} 3(100 \mu \mathrm{l}, 1 \mathrm{M})$ were added. The mixture was allowed to stand for 30 minutes. The phenols were determined by the colorimetric method at $765 \mathrm{~nm}$. Total phenol values are expressed in terms of Gallic acid equivalent $(\mu \mathrm{g} / \mathrm{g}$ of fresh weight). Total phenol contents were calculated as a Gallic acid from a calibration curve.

\section{Total Protein}

Biuret method of Racusen and Johnstone (1961) was adopted for the estimation of total soluble protein contents. $2.0 \mathrm{~g}$ of plant material was crushed in the ice chilled pestle and mortar containing $0.2 \mathrm{~g}$ of PVP (polyvinylpyrrolidone) with $8 \mathrm{ml}$ of $0.1 \mathrm{M}$ phosphate buffer at $4^{\circ} \mathrm{C}$. For the extraction of total soluble protein contents, slurry was centrifuged at $10,000 \mathrm{rpm}$ for $10 \mathrm{mins}$ at $4^{\circ} \mathrm{C}$. The supernatant was used for further analysis.

\section{Steviol Glycosides Assay}

Sweet glycosides were extracted from the leaves when the plants were 6 months old. The metabolites were extracted according to the method of Kolb et al. (2001) with slight modifications. $1 \mathrm{~g}$ of dried and powdered leaves was immersed in $100 \mathrm{ml}$ of $70 \%(\mathrm{v} / \mathrm{v})$ ethanol in a conical flask. The sample was incubated for $30 \mathrm{~min}$ in a water bath at $70^{\circ} \mathrm{C}$ with continuous shaking. After cooling, a $10 \mathrm{ml}$ aliquot was filtered (Whatman No. 42). Finally, the sample was passed 
through a nylon syringe filter with a pore size of $0.22 \mu \mathrm{m}$, and then $20 \mu \mathrm{l}$ of sample was analyzed using a Shimadzu CLASS-VP V6.13 SP1.A, $250 \times 4.6 \mathrm{~mm}, 5 \mu \mathrm{m}$ in diameter, reverse phase $\mathrm{C}-18$ silica column HPLC system. The mobile phase for rebaudioside-A consisted of acetonitrile and water in a ratio of 60:40 (by volume) at $\mathrm{pH}$ 5.6. The flow rate was adjusted to $1 \mathrm{ml} \mathrm{min}^{-1}$. The peaks of steviol glycosides were detected at a wavelength of $210 \mathrm{~nm}$. Chromatographic peaks were confirmed and quantified by comparing their retention times with rebaudioside $A$ standard after obtaining a calibration curve. All chromatographic analyses were performed isocratically at ambient temperature. The standards for rebaudioside A, (Code No. 183-02361) used for the quantification were purchased from Wako Pure Chemical Industries Co., Ltd. (Osaka, Japan). Water, acetonitrile, and ethanol were of chromatographic grade (Fischer) and all other chemicals were of analytical grade.

\section{Statistical analysis}

Data were analyzed for significance using one-way analysis of variance (ANOVA) and the differences contrasted using Duncan's multiple range test (DMRT) at $p \leq 0.05$. All statistical analyses were performed using the Statistical Package for Social Sciences (SPSS, version 11.5).

\section{Conclusion}

The effects of different nutritional components on stevia plant are variable and the ongoing research by different mixtures will be open. In above study, according to physiological and biochemical findings, we can conclude the highest effect can be earned by using G11 planting bed with some modification on cocopeat percentage, which may raise the amounts ofrebaudiosides.

\section{References}

Arnon DI (1949) Copper enzymes in isolated chloroplasts, polyphenoloxidase in Betavulgaris. Plant Physiol. 24: 1-15.

Brandle J, Telmer P (2007) Steviol glycoside biosynthesis. Phytochemistry, 68: 1855-1863.

Cacciola F, Delmontea P, Jaworska K, Dugo P, Mondello L, Rader J (2011) Employing ultra-high-pressure liquid chromatography as the second dimension in a comprehensive two-dimensional system for analysis of Stevia rebaudiana extracts. J Chromatography A, 1218: 2012-2018.

Das K, Dang R, Shivananda TN (2008) Influence of biofertilizers on the availability of nutrients $(N, P$, and $K$ ) in the soil in relation to growth and yield of Stevia rebaudiana grown in South India Inter J Appl Natural Products, 1: 20-24.

Fronza D, Folengatti MV (2003) Water consumption of the stevia (Stevia rebaudiana (Bert.) Bertoni) crop estimated through microlysimeter. Agric Sci. 60: 95-599.

Geuns J (2003) Stevioside. Phytochemistry, 64: 913-921.

Ghanta, S, Banerjee A, Poddar, A, Chattopadhyay S (2007) Oxidative DNA damage preventive activity and antioxidant potential of Stevia rebaudiana (Bert.), a natural sweetener. J Agric Food Chem. 55: 10962-10967.

Giri B, Kapoor R, Mukerji KG (2003) Influence of arbuscular mycorrhizal fungi and salinity on growth, biomass and mineral nutrition of Acacia auriculiformis. Biol Fertil Soils, 38: 170-175.

Jefferies P, Gianinazzi S, Perotto S, Turnau K, Barea JM (2003) The contribution of arbuscular mycorrhizalfungi in sustainable maintenance of plant health and soil fertility. Biol Fertil Soils, 37: 1-16.

Kolb N, Herrera JL, Ferreyra DJ, Uliana RF (2001) Analysis of sweet diterpene glycosides from Stevia rebaudiana: improved HPLC method. J Agric Food Chem. 49: 45384541.

Liu X, Ren G, Shi Yan (2011) The effect of organic manure and chemical fertilizer on growth and development of Stevia rebaudiana Bertoni. Energy Procedia, 5: 1200-1204.

MamtaRahi P, Pathania V, Gulati A, Singh B, Bhanwra RK, Tewari $R$ (2010) The stimulatory effect of phosphatesolubilizing bacteria on plant growth, stevioside and rebaudioside-A contents of Stevia rebaudianaBertoni. Appl Soil Ecol. 46: 222-229.

Mandal S, Evelin H, Giri B, Singh V, Kapoor R (2013) Arbuscular mycorrhiza enhances the production of stevioside and rebaudioside-A in Stevia rebaudiana via nutritional and non-nutritional mechanisms. Appl Soil Ecol. 72: 187-194.

Pal P, Kumar R, Guleria V, Mahajan M, Prasad R, Pathania V, Gill B, Singh D, Chand G, Singh B, Singh R, Ahuja P (2015) Crop-ecology and nutritional variability influence growth and secondary metabolites of Stevia rebaudiana Bertoni. BMC Plant Biology, 15:67.

Patil NM (2010) Biofertilizer effect on growth, protein and carbohydrate content in stevia rebaudianavar Bertoni. Recent Res Sci Technol. 2: 42-44.

Racusen D, Johnstone DB (1961) Estimation of protein in cellular material. Nature. 191: 292-493.

Schaarschmidt S, Roitsch T, Hause B (2006). Arbuscular mycorrhiza induces gene expression of the apoplasticinvertase LIN6 in tomato (Lycopersicon esculentum) roots. J Exp Bot. 57: 4015-4023.

Shock C (1982) Experimental cultivation of Rebaudi's stevia in California. University of California - Davis, Agronomy Progress Report, 122 April.

Singh S, and Rao G (2005) Stevia: The herbal sugar of $21^{\text {st }}$ century. Sugar Tech. 71: 17-24.

Soejarto D (2002) Botany of Stevia and Stevia rebaudiana. In Kinghorn AD (ed) Stevia: The genus Stevia. London, New York, Taylor, and Francis, 18-39.

Thimmaiah SR, (2004). Standard methods of biochemical analysis. Kalyani Publishers, New Delhi 545.

Vafadar F, Amooaghaie R, Otroshy M (2014) Effects of plant growth promoting rhizobacteria and arbuscular mycorrhizal fungus on plant growth, stevioside, NPK, and chlorophyll content of stevia rebaudiana. J Plant Interact. 9: 128-136.

Wu QS, Zou YN, He XH, Luo P (2011) Arbuscular mycorrhizal fungi can alter some root characters and physiological status in trifoliate orange (Poncirus trifoliata L. Raf.) seedlings. Plant Growth Regul. 65: 273-278.

Yang J, Liu X, Shi Y (2013) Effect of differently mixed fertilizer on yield, Quality, and economic benefits in Stevia rebaudiana Bertoni. Adv J Food Sci Technol. 5: 588-591. 